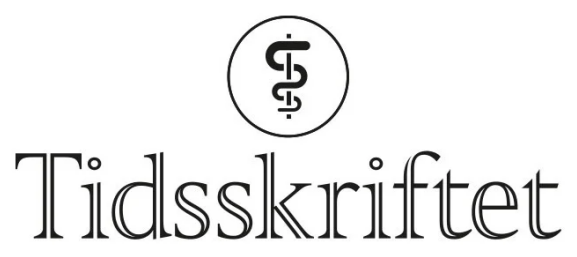

DEN NORSKE LEGEFORENING

\title{
Immunsystemets rolle i alvorlig covid-19
}

\author{
LEDER
}

\section{MARIA BELLAND OLSEN}

m.b.olsen@ous-research.no

Maria Belland Olsen er ph.d., molekylærbiolog og forsker ved Institutt for indremedisinsk forskning ved Oslo universitetssykehus, Rikshospitalet. Hun jobber med immunsystemets rolle i

kardiovaskulær og metabolsk sykdom.

Forfatteren har fylt ut ICMJE-skjemaet og oppgir ingen interessekonflikter.

\section{IDA GREGERSEN}

Ida Gregersen er ph.d., klinisk ernæringsfysiolog og forsker ved Institutt for indremedisinsk forskning ved Oslo universitetssykehus, Rikshospitalet. Hun jobber med immunsystemets rolle i kardiovaskulær og metabolsk sykdom.

Forfatteren har fylt ut ICMJE-skjemaet og oppgir ingen interessekonflikter.

\section{Ukontrollert immunrespons mot SARS-CoV-2 kan føre til vevsskade, organsvikt og død. Jo mer vi forstår av denne prosessen, jo nærmere kan vi komme en bedre behandling.}

Infeksjon med SARS-CoV-2 starter ved at viruset trenger inn i en celle, for eksempel en lungeepitelcelle. Viruset bruker cellens maskineri for å formere seg, noe som fører til at cellen dør. Dette frigir signalstoffer til omliggende celler som videre påkaller immunceller - monocytter, makrofager og T-celler. I en normal immunrespons vil dette føre til opprydning og til at viruset blir eliminert. Betennelsen forblir lokal og er fordelaktig. Hos noen pasienter med covid-19 skyter imidlertid immunresponsen over mål, den blir for kraftig og løper løpsk. På dette stadiet er ikke betennelsesreaksjonen lenger avhengig av viruset for å aktiveres, den er selvdreven. I lungene kan en slik ukontrollert immunrespons gi vevsskade og i verste fall føre til respirasjonssvikt. Systemisk kan det forårsake skader på hjertet og andre organer, og dessuten organsvikt og $\mathrm{d} ø \mathrm{~d}(\underline{1})$. Mye tyder på at mens viruset helt klart utløser covid-19, så er det ikke selve viruset som driver den kraftige betennelsen som karakteriserer de dårligste pasientene.

For å bedre forstå hvorfor noen utvikler en overaktiv immunreaksjon, har flere studier fors $\emptyset \mathrm{kt}$ å identifisere en covid-19-spesifikk immunsignatur (2-4). Covid-19-pasienter har store endringer $i$ antall og sammensetning av immunceller sammenliknet med friske personer. Dette gjelder omtrent alle typer immunceller: antistoffproduserende B-celler, Tceller, monocytter og granulocytter. For de sykeste pasientene viser flere av immuncellene 
en fenotype preget av dysregulering og utmattelse, altså ikke en gjeng med celler klare for en velorganisert kamp. Dette kan være med på å forklare hvorfor immunresponsen blir dysfunksjonell. Kanskje overraskende finner flere studier svak eller ingen sammenheng mellom mengde virus og alvorlighetsgrad av covid-19 (2-4). I tråd med dette har medikamenter som har blitt gitt for å dempe virusmengde, eksempelvis remdesivir, ikke vist effekt på forløp eller overlevelse blant sykehusinnlagte pasienter (5).

En annen mulig grunn til at SARS-CoV-2 overaktiverer immunsystemet, kan være gjennom påvirkning av reseptoren den bruker som inngangsport til cellen. Inngangsporten ACE2 (angiotensinkonverterende enzym 2) er, i tillegg til å være en svært viktig medspiller i det blodtrykksregulerende systemet, en regulator av betennelse. Kort forklart kan infeksjon med SARS-CoV-2 være betennelsesfremmende gjennom å nedregulere ACE2 og dermed hindre reseptoren i å utføre sine betennelsesdempende funksjoner (므).

"Kanskje overraskende finner flere studier svak eller ingen sammenheng mellom mengde virus og alvorlighetsgrad av covid-19"

Trolig er svaret på hvorfor bare noen blir alvorlig syke, kompleks og avhengig av mange faktorer, deriblant gener. Flere genetiske variasjoner er vist å ha sammenheng med et alvorlig forløp, blant annet genvarianter av ACE2-genet $(7, \underline{8})$ og av flere immunregulerende faktorer. Eksempelvis er det i en studie av unge og ellers friske menn vist at alvorlig covid-19 er assosiert med en genvariant av TLR7-genet, som koder for en reseptor som gjenkjenner virus. Denne genvarianten førte til at pasientenes immunforsvar ikke klarte å føre en målrettet betennelsesreaksjon, noe som kan være med på å forklare det alvorlige sykdomsforløpet (9.). I en stor genetisk studie ble det vist at personer med blodtype $O$ hadde lavere risiko for å utvikle alvorlig covid-19, og at flere gener som er involvert i immunresponsen, var assosiert med risiko for alvorlig sykdom (므).

En ukontrollert immunrespons er alvorlig, og kan føre til videre vevsskade, organsvikt og $\mathrm{d} ø \mathrm{~d}(\underline{1})$. Medikamenter som modulerer immunresponsen slik at den ikke lenger er skadelig, vil trolig være viktig for å bedre behandlingen av alvorlig covid-19.

\section{LITTERATUR}

1. Tay MZ, Poh CM, Rénia L et al. The trinity of COVID-19: immunity, inflammation and intervention. Nat Rev Immunol 2020; 20:363-74. [PubMed][CrossRef]

2. Laing AG, Lorenc A, Del Molino Del Barrio I et al. A dynamic COVID-19 immune signature includes associations with poor prognosis. Nat Med 2020; 26: 1623-35. [PubMed][CrossRef]

3. Schulte-Schrepping J, Reusch N, Paclik D et al. Severe COVID-19 is marked by a dysregulated myeloid cell compartment. Cell 2020; 182:1419-1440.e23. [PubMed][CrossRef]

4. Wilk AJ, Rustagi A, Zhao NQ et al. A single-cell atlas of the peripheral immune response in patients with severe COVID-19. Nat Med 2020; 26:1070-6. [PubMed][CrossRef]

5. Pan H, Peto R, Karim QA et al. Repurposed antiviral drugs for COVID-19-interim WHO SOLIDARITY trial results medRxiv 2020 doi: 2020.10.15.20209817. [CrossRef]

6. Samavati L, Uhal BD. ACE2, much more than just a receptor for SARS-COV-2. Front Cell Infect Microbiol 2020; 10:317. [PubMed][CrossRef]

7. Benetti E, Tita R, Spiga O et al. ACE2 gene variants may underlie interindividual variability and susceptibility to COVID-19 in the Italian population. Eur J Hum Genet 2020; 28: 1602-14. [PubMed] [CrossRef]

8. Hou Y, Zhao J, Martin W et al. New insights into genetic susceptibility of COVID-19: an ACE2 and TMPRSS2 polymorphism analysis. BMC Med 2020; 18: 216. [PubMed][CrossRef]

9. van der Made CI, Simons A, Schuurs-Hoeijmakers J et al. Presence of genetic variants among young men with severe COVID-19. JAMA 2020;324: 663-73. [PubMed][CrossRef] 
10. Ellinghaus D, Degenhardt F, Bujanda L et al. Genomewide association study of severe covid-19 with respiratory failure. N Engl J Med 2020;383: 1522-34. [PubMed][CrossRef]

Publisert: 14. desember 2020. Tidsskr Nor Legeforen. DOI: 10.4045/tidsskr.20.086o

(C) Tidsskrift for Den norske legeforening 2023. Lastet ned fra tidsskriftet.no 26. april 2023. 